\title{
Continuous gluconic acid production by Aureobasidium pullulans with and without biomass retention
}

\author{
Savas Anastassiadis* \\ Pythia Institute of Biotechnology of Research in Biotechnology \\ Co., Vat. \#: 108851559 \\ Avgi/Sohos, 57002 \\ Thessaloniki, Greece \\ Tel. 302395051324 \\ Fax. 302395051470 \\ E-mail: sanasta@env.duth.gr \\ Hans-Jürgen Rehm \\ Institute of Molecular Microbiology and Biotechnology \\ University of Münster \\ Corrensstr. 3, 48149 Münster, Germany \\ (retired Professor)
}

Website: http://www.greekbiotechnologycenter.gr

Financial support: The work has been carried out at the Institute of Biotechnology 2 of Research Center Jülich (formerly known as Nuclear Research Center Jülich, Germany) and was financed by Haarmann and Reimer, a daughter company of the company Bayer, Leverkusen, Germany.

Keywords: biomass immobilization, continuous fermentation, cross over filtration, gluconic acid fermentation, reaction technique, residence time.

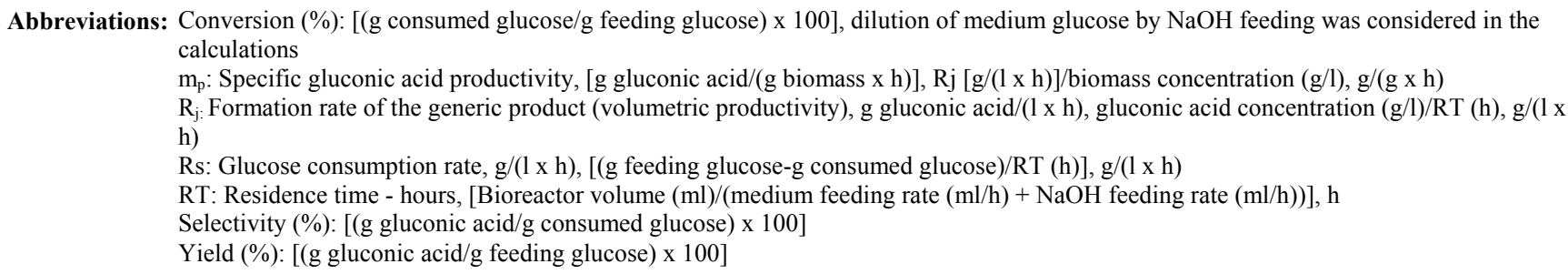

New alternative processes for the continuous production of gluconic acid by Aureobasidium pullulans, using biomass retention by cell immobilization or cross over filtration, are described in the present work. $315 \mathrm{~g} / \mathrm{l}$ gluconic acid was continuously produced in chemostat cultures at 21 hrs residence time without any biomass retention. $260 \mathrm{~g} / \mathrm{l}$ gluconic acid was produced in fluidized bed reactor at $21 \mathrm{hrs}$ residence time. The support carrier was overgrown resulting in limitations of oxygen transfer towards the inner layers of immobilized biomass. $375 \mathrm{~g} / \mathrm{l}$ gluconic acid was produced under continuous cultivation at 22 hrs of residence time with a formation rate for the generic product of $17 \mathrm{~g} /(\mathbf{l} \mathrm{x}$ h) and a specific gluconic acid productivity of only $0.74 \mathrm{~g} /\left(\begin{array}{lll}\mathrm{g} & \mathrm{x} & \mathrm{h}\end{array}\right)$, using biomass retention by cross over filtration. $370 \mathrm{~g} / \mathrm{l}$ were obtained at 19 hrs RT and $100 \%$ conversion with $25 \mathrm{~g} / \mathrm{l}$ biomass and a formation rate of $19 \mathrm{~g} /\left(\begin{array}{lll}1 & \mathrm{x} & \mathrm{h}\end{array}\right)$. At $100 \%$ conversion, a selectivity of only $78 \%$ was determined at
22 hrs and of $77 \%$ at 19 hrs RT, because of the very high biomass concentration. Biomass retention makes it possible to break the existing link between growth and residence time.

As a multifunctional carbonic acid, belonging to the bulk chemicals and due to its physiological and chemical characteristics, gluconic acid itself, the gluconolatone form and its salts (e.g. alkali metal salts, in especially sodium gluconate) have found extensively versatile uses in the chemical, pharmaceutical (e.g. iron and calcium deficiency), food, beverage, textile and other industries (Hustede et al. 1989; Anastassiadis et al. 2003; Znad et al. 2004). Additionally, it can be exploited for cleaning purposes (e.g. diary industry) as well as for the extraction of trace elements like calcium, copper and iron. Gluconic acid can have further applications for the solubilization of phosphate (Fenice et al. 2000; Vassilev et al. 2001; Rodríguez et al. 2004) and as a cement additive in the

*Corresponding author 
Table 1. Results of the continuous gluconic acid fermentation with residence times of 21 and $25 \mathrm{hrs}(3 \mathrm{~g} / \mathrm{l}$ $\mathrm{NH}_{4} \mathrm{Cl}, 450 \mathrm{~g} / \mathrm{l}$ glucose, $1 \mathrm{mM}$ iron, $5 \mathrm{mM}$ manganese, $\mathrm{pH}$ 6.5, $30^{\circ} \mathrm{C}$ and $155 \%$ oxygen saturation).

\begin{tabular}{|l|c|c|c|}
\hline \multicolumn{1}{|c|}{ Residence time } & hr & $\mathbf{2 1}$ & $\mathbf{2 5}$ \\
\hline Biomass & $\mathrm{g} / \mathrm{l}$ & 6.8 & 6.8 \\
\hline Optical density & $660 \mathrm{~nm}$ & 37 & 37 \\
\hline Glucose & $\mathrm{g} / \mathrm{l}$ & 80 & 70 \\
\hline Gluconic acid & $\mathrm{g} / \mathrm{l}$ & 315 & 330 \\
\hline Rj & $\mathrm{g} /(\mathrm{l} \times \mathrm{h})$ & 15 & 13.3 \\
\hline mp & $\mathrm{g} /(\mathrm{g} \times \mathrm{h})$ & 2.2 & 1.9 \\
\hline Conversion & $\%$ & 81 & 82.5 \\
\hline Yield & $\%$ & 71 & 76 \\
\hline Selectivity & $\%$ & 92 & 92.1 \\
\hline
\end{tabular}

construction industry, because it enhances the cement's resistance and stability under extreme climatic conditions, e.g. frost and water (Singh, 1976; Hustede et al. 1989).

Numerous methods have been extensively described for the production of gluconic acid, including chemical and electrochemical catalysis, enzymatic biocatalysis in enzyme bioreactor, microbial production using free growing or immobilized cells of either Gluconobacter oxydans or Aspergillus niger. The immobilization of whole cells or glucose oxidase enzyme by various techniques has often been reported to be a useful approach to the production of gluconic acid or other microbial metabolites (Hartmeier and Döppner, 1983; Pronk et al. 1989; Sakurai et al. 1989; Gromada and Fiedurek, 1997; Nakao et al. 1997; Kara and Bozdemir, 1998; Velizarov and Beschkov, 1998; Anastassiadis et al. 1999; Sankpal et al. 1999; Bang et al. 1999; Ferraz et al. 2000; Bao et al. 2001; Blandino et al. 2001; Klein et al. 2002; Sankpal and Kulkarni, 2002; Anastassiadis et al. 2003; Godjevargova et al. 2004; Anastassiadis et al. 2005; Mukhopadhyay et al. 2005). Fluidized bed reactors have been often used for several fermentation applications, in especially for anaerobic processes. The separation of the biocatalyst is practically connected with high expenses, substantially influencing the economics of a fermentation process. Cell immobilization would therefore be an economically efficient alternative option for the production of gluconic acid under either batch or continuous cultivation. Sankpal and Kulkarni (2002) described gluconic acid fermentation by immobilized cells of $A$. niger on a highly porous cellulose support.

Biomass retention by immobilization on porous sinter glass or by cross over filtration was applied in present work in order to investigate the feasibility of a further acceleration of continuous gluconic acid production and of the maximization of product concentration by an isolated Aureobasidium pullulans strain, as a comparison with the continuous cultivation of free growing cells.

\section{MATERIALS AND METHODS}

\section{Microorganism}

Aureobasidium pullulans (de Bary) Arnaud isolate Nr. 70 (DSM 7085), which was isolated from wild flowers (Jülich, Germany) was used during the entire work (Anastassiadis et al. 1999; Anastassiadis et al. 2003; Anastassiadis et al. 2005). Yeast malt extract agar plates (YME), inoculated with Aureobasidium pullulans, were incubated for 2-3 days and stored at $4^{\circ} \mathrm{C}$. The inoculum $(10 \%)$ was prepared by transferring of cells from agar plates into $500 \mathrm{ml}$ shake flasks with buffels on a medium containing (g/l): Glucose $30 \mathrm{~g} / 1, \mathrm{NH}_{4} \mathrm{Cl} 3 \mathrm{~g} / 1, \mathrm{KH}_{2} \mathrm{PO}_{4} 1.4 \mathrm{~g} / 1, \mathrm{MgSO}_{4}$ x $7 \mathrm{H}_{2} \mathrm{O} 0.35$ $\mathrm{g} / \mathrm{l}, \mathrm{MnSO}_{4}$ x $4 \mathrm{H}_{2} \mathrm{O} 5 \mathrm{mM}, \mathrm{FeSO}_{4} \times 7 \mathrm{H}_{2} \mathrm{O} 1 \mathrm{mM}, \mathrm{CuSO}_{4}$ x $5 \mathrm{H}_{2} \mathrm{O} 4 \mu \mathrm{M}(1 \mathrm{mg} / \mathrm{l}), \mathrm{ZnSO}_{4} \times 7 \mathrm{H}_{2} \mathrm{O} 0.01 \mathrm{~g} / 1, \mathrm{CoSO}_{4} \times 7$ $\mathrm{H}_{2} \mathrm{O} 4 \mathrm{mg} / \mathrm{l}, \mathrm{H}_{3} \mathrm{BO}_{3} 0.04 \mathrm{~g} / \mathrm{l}, \mathrm{CaCl}_{2} 0.1 \mathrm{~g} / \mathrm{l}, \mathrm{NaCl} 0.1 \mathrm{~g} / \mathrm{l}$, citric acid $2.5 \mathrm{~g} / 1, \mathrm{Na}_{2} \mathrm{MoO}_{4} \times 2 \mathrm{H}_{2} \mathrm{O} 0.2 \mathrm{mg} / \mathrm{l}$, thiamine$\mathrm{HCl} 2 \mathrm{mg} / \mathrm{l}$, biotin $0.25 \mathrm{~g} / \mathrm{l}$, pyridoxine- $\mathrm{HCl} 0.625 \mathrm{mg} / \mathrm{l}, \mathrm{Ca}-$ D-pantothenate $0.625 \mathrm{mg} / \mathrm{l}$, nicotinic acid $0.5 \mathrm{mg} / \mathrm{l}$.

\section{Culture conditions}

For the investigation of continuous gluconic acid fermentation with or without biomass retention, cells were grown in a 5 litre fermenter (Biostat E, Braun-Diessel) at a working volume of $31,1000 \mathrm{rpm}, \mathrm{pH} 6.5$ and $30^{\circ} \mathrm{C}$ in chemostat mode on a basal defined medium containing (g/l): varying glucose concentration (s. results), $\mathrm{NH}_{4} \mathrm{Cl} 3$ $\mathrm{g} / \mathrm{l}, \mathrm{KH}_{2} \mathrm{PO}_{4} 1.4 \mathrm{~g} / \mathrm{l}, \mathrm{MgSO}_{4}$ × $7 \mathrm{H}_{2} \mathrm{O} 0.35 \mathrm{~g} / 1, \mathrm{MnSO}_{4}$ × 4 $\mathrm{H}_{2} \mathrm{O} 5 \mathrm{mM}, \mathrm{FeSO}_{4} \times 7 \mathrm{H}_{2} \mathrm{O} 1 \mathrm{mM}, \mathrm{CuSO}_{4} \times 5 \mathrm{H}_{2} \mathrm{O} 4 \mu \mathrm{M}(1$ $\mathrm{mg} / \mathrm{l}), \mathrm{ZnSO}_{4} \times 7 \mathrm{H}_{2} \mathrm{O} 0.01 \mathrm{~g} / 1, \mathrm{CoSO}_{4} \times 7 \mathrm{H}_{2} \mathrm{O} 4 \mathrm{mg} / \mathrm{l}$, $\mathrm{H}_{3} \mathrm{BO}_{3} 0.04 \mathrm{~g} / 1, \mathrm{CaCl}_{2} 0.1 \mathrm{~g} / 1, \mathrm{NaCl} 0.1 \mathrm{~g} / 1$, citric acid 2.5 $\mathrm{g} / \mathrm{l}, \mathrm{Na}_{2} \mathrm{MoO}_{4}$ × $2 \mathrm{H}_{2} \mathrm{O} 0.2 \mathrm{mg} / \mathrm{l}$, thiamine- $\mathrm{HCl} 2 \mathrm{mg} / \mathrm{l}$, biotin $0.25 \mathrm{~g} / \mathrm{l}$, pyridoxine- $\mathrm{HCl} 0.625 \mathrm{mg} / \mathrm{l}, \mathrm{Ca}-\mathrm{D}$-pantothenate $0.625 \mathrm{mg} / \mathrm{l}$, nicotinic acid $0.5 \mathrm{mg} / 1$ [24,25,2]. Vitamins and $\mathrm{NH}_{4} \mathrm{Cl}$ were added separately to autoclaved medium (30-60 $\min$ at $121^{\circ} \mathrm{C}$ ) by sterile filtration (Sartorius filter, Göttingen, Germany). The fermentations were carried out at $30^{\circ} \mathrm{C}$ and $\mathrm{pH} 6.5$ automatically adding a $45 \% \mathrm{NaOH}$ solution.

\section{Fermentation equipment}

The fermentations were carried out in agitation 5 litre fermenters (Figure 1) (Biostat M, Diessel-Braun, 


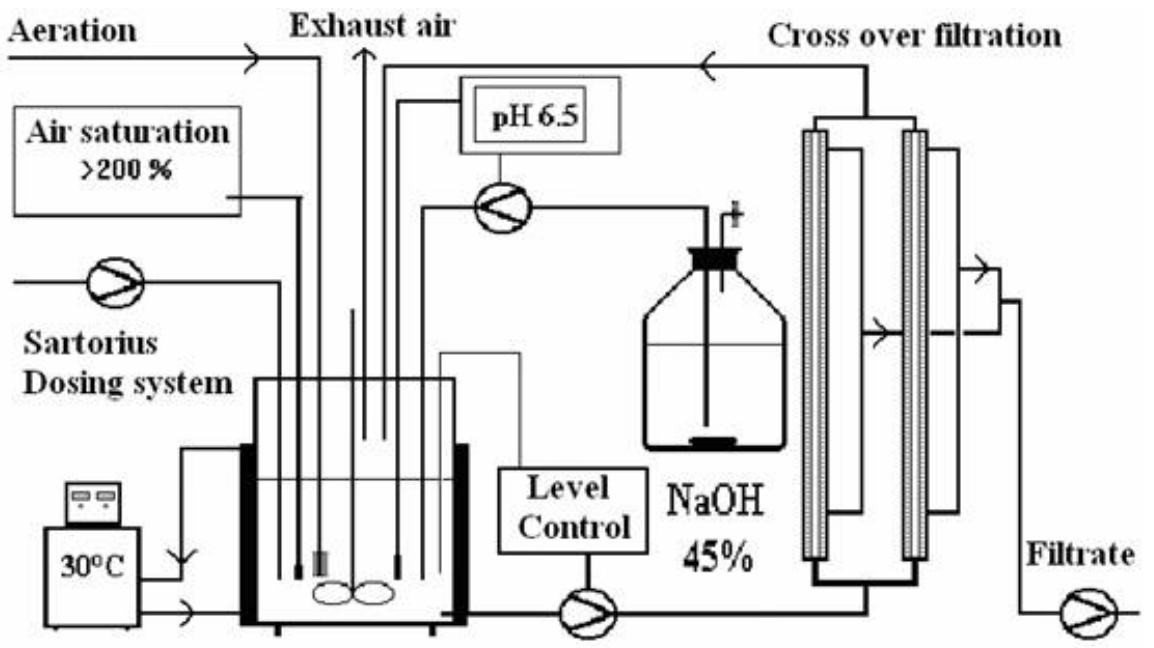

Figure 1. Flow scheme of a stirrer fermenter with intergraded cross over filtration.

Germany). From the concept, the fermenters were laid out for the continuous mode of operation. The fermenters worked according to the principle of chemostat, i.e. by delimitation of a growth factor and at a constant supply of nutritive solution into fermenter a stationary condition (steady state) can be adjusted. The temperature was controlled using laboratory thermostats Lauda M3 (Meßgerätewerk Lauda, D6970-Lauda-Königshofen). The air saturation (\%) was measured as has been reported in Anastassiadis et al. (2005). A sufficient oxygen supply was ensured adding pure oxygen over two parallel attached sterile filters (T-fitting) into the supply line, in order to maintain air saturations higher than $100 \%$ in fermenter (Anastassiadis et al. 2005). The oxygen was distributed by means of a sinter glass frit in the culture liquid. The exhaust gas stream left likewise over two parallel sterile filters the fermenter. A condenser prevented the discharge of water over the exhaust upstream of air. The experimental setup of such a fermenter is schematically represented in Figure 1.

The fermentation medium was continuously added into the fermenter using a precision gravimetric dosing system (Sartorius, Göttingen, Germany) and a peristalticpump (Watson Marlow). Periodically, an antifoaming agent was pumped to the fermenter using a time switch clock (15 sec performance every $1.5 \mathrm{hrs}$ ). The residence time was determined based on the fermenter working volume via the total medium and $\mathrm{NaOH}$ flux. More than five residence times were required for achieving steady state conditions and the cultivation in each mode was continued until the culture medium in fermenter was replaced at least five times.

\section{Biomass retention by cross over filtration}

The experiments for the continuous production of gluconic acid by biomass retention by means of cross over filtration were carried out in a 5 litre stirrer fermenter. For the cross over filtration, two parallel connected autoclavable microfiltration tubing modules (cross over filtration) were attached to the vessel (Figure 1). Fermenter, filters, medium and $\mathrm{NaOH}$ solution were externally sterilized in a large autoclave. In case of clogging appearances, the modules were exchanged or were cleaned by turning periodically the pumping direction backwards. The goal was implemented by taking off a part of the fermentation broth as filtrate and thus it is increased the stationary biomass concentration in bioreactor. At the same time, the discharge remainder (Bleed), containing fermentation broth and biomass, was taken out of the fermenter by means of a second peristaltic pump. Both pumps were simultaneously controlled by a level control system. By this way, it became feasible to adjust a constant relationship between both types of discharges. The level control probe (Weathston's bridge) was calibrated, enabling the proportional adjustment of desired level of filling under constant fermentation conditions. For safety reasons, the substrate pump was also interconnected to this control system and at reaching a certain (adjustable) level of bioreactor broth the pump was shut down automatically. The fermentation was performed at $30^{\circ} \mathrm{C}, \mathrm{pH} 6.5$ and $290 \%$ air saturation.

\section{Biomass retention by biomass immobilization}

The experiments with biomass immobilization were carried out in a fluidized bed reactor at a working volume of about 0.9 litre (Figure 2). For the immobilization of biomass, about $350 \mathrm{~g}$ of porous sinter glass beads $\left(\mathrm{SIRAN}^{\mathrm{R}}\right)(\mathrm{Schott}$ AG, Mainz, Germany) was added in fluidized bed reactor, 
resulting in the ideal case to a total working volume of 0.9 litre. Sinter glass balls with a three-dimensional cavity structure and the

following characteristics were used: ball form with 1-2 mm diameter, $60 \%$ porosity, distribution of pore sizes of $60-300$ $\mu \mathrm{m}$, from borosilicate. The carrier drawn away from fermenter was collected in a cyclone (precipitation vessel) in order to avoid clogging of tubing lines. The oxygen electrode was placed in an external glass vessel and the $\mathrm{pH}$ electrode was placed in a conical glass vessel, which was located between the large circulation pump and the fluidized bed fermenter, in order to avoid fouling by biofilm formation. Furthermore, the $\mathrm{pH}$ was periodically checked using an external $\mathrm{pH}$ meter and readjusted. The reactor was securely placed and stabilized on a stand. An automatic dosing system (Sartorius, Germany) was used for the constant feeding rate of fermentation medium (Figure 2 ). Because of the very high relationship between substrate flow rate and recirculation flow rate, the fluidized bed reactor can be considered as a regular stirrer fermenter.

\section{Analysis}

Optical density $\left(\mathrm{OD}_{660 \mathrm{~nm}}\right)$, dry biomass (filter method) and the concentration of glucose and gluconic acid were determined as has described in previous works (Anastassiadis, 1993; Anastassiadis et al. 1999; Anastassiadis et al. 2003; Anastassiadis et al. 2005).

\section{Ammonium analysis}

Ammonium nitrogen was analyzed as has been described in Anastassiadis et al. (2002).

\section{RESULTS}

Novel superior processes were developed and optimized for the continuous and discontinuous production of gluconic acid by isolated strains of Aureobasidium pullulans during an extensive process development program (Anastassiadis

Table 2. Continuous gluconic acid fermentation with biomass retention by means of cross over filtration.

\begin{tabular}{|l|c|c|c|}
\hline \multicolumn{1}{|c|}{ Residence time } & hr & $\mathbf{2 2}$ & $\mathbf{1 9}$ \\
\hline Biomass & $(\mathrm{g} / \mathrm{l})$ & 23 & 25 \\
\hline Gluconic acid & $(\mathrm{g} / \mathrm{l})$ & 375 & 370 \\
\hline $\mathrm{Rj}$ & $(\mathrm{g} / \mathrm{l} \times \mathrm{h})$ & 17 & 19.5 \\
\hline $\mathrm{m}_{\mathrm{p}}$ & $(\mathrm{g} / \mathrm{g} \times \mathrm{h})$ & 0.74 & 0.78 \\
\hline Conversion & $(\%)$ & 100 & 100 \\
\hline Selectivity & $(\%)$ & 78 & 77 \\
\hline
\end{tabular}

et al. 1999; Anastassiadis et al. 2003; Anastassiadis et al. 2005). A defined fermentation medium was composed and optimized, which makes it easy to reproduce those data. Completing the process optimization program, reactiontechnical investigations were accomplished, in order to examine the transferability of obtained results and to test different fermentation process variants (e.g. batches, fed batches, continuous fermentation without and with biomass retention) for the production of gluconic acid by Aureobasidium pullulans isolate 70 (DSM 7085) (Anastassiadis et al. 1999).

\section{Continuous production of gluconic acid by free growing cells in stirrer fermenter}

The continuous gluconic fermentation by free growing cells of $A$. pullulans and without any biomass retention was carried out in a 5 litre fermenter under optimized conditions $\left(\mathrm{pH} \quad 6.5,30^{\circ} \mathrm{C}\right.$, air saturation $\left.120-180 \%\right)$, using an extensively optimized defined medium (Anastassiadis et al. 1999). More than $220 \mathrm{~g} / 1$ were produced under continuous steady state cultivation in previous chemostat studies (Anastassiadis et al. 2005). With $450 \mathrm{~g} / 1$ glucose in feeding medium and at $155 \%$ air saturation, $315 \mathrm{~g} / \mathrm{l}$ gluconic acid were continuously produced under steady state conditions at $21 \mathrm{hrs}$ residence time with $6.8 \mathrm{~g} / \mathrm{l}$ biomass and a formation rate for the generic product of $15 \mathrm{~g} /(1 \mathrm{x} \mathrm{h})$. Figure 3 shows the continuous production of gluconic acid at 25 hrs residence time, reaching steady state conditions about $170 \mathrm{hrs}$ after the inoculation of fermenter. Table 1 illustrates the results that have been achieved at residence times of 21 and $25 \mathrm{hrs} .330 \mathrm{~g} / \mathrm{l}$ were continuously produced at a conversion of $82.5 \%$ and $92 \%$ selectivity with a formation rate for the generic product of $13.2 \mathrm{~g} /(1 \mathrm{x} \mathrm{h})$ and a biomass of $6.8 \mathrm{~g} / \mathrm{l}$, corresponding to a specific productivity of $1.94 \mathrm{~g} /(\mathrm{g} \times \mathrm{h})$. For comparison, a maximum specific productivity of about $9.3 \mathrm{~g} /(\mathrm{g} \mathrm{x} \mathrm{h})$ and formation rate of about $18.6 \mathrm{~g} /(1 \times \mathrm{h})$ were reached in a chemostat under optimized conditions without any biomass retention at very short times of about $11.8 \mathrm{hrs}$ (data not shown here). The fermentation continued to stably run without any technical and microbial stability problems for a very long period of time. A continuous gluconic acid fermentation using a new strain of A. pullulans, which was isolated at the Research in Biotechnology Co. (Greece) was running for about 1 year without any microbial stability problems, showing again the stability of Aureobasidium process.

\section{Continuous gluconic acid production by immobilized cells}

The continuous production of gluconic acid by cell immobilization on porous sinter glass (Schott, Germany) was studied in a fluidized bed reactor under optimum fermentation condition, using an optimized defined medium with $450 \mathrm{~g} / \mathrm{l}$ glucose. The fermenter was initially inoculated with a two days culture of Aureobasidium pullulans isolate 70 (DSM 7085). The fermenter performed under batch conditions at the beginning of fermentation and the 


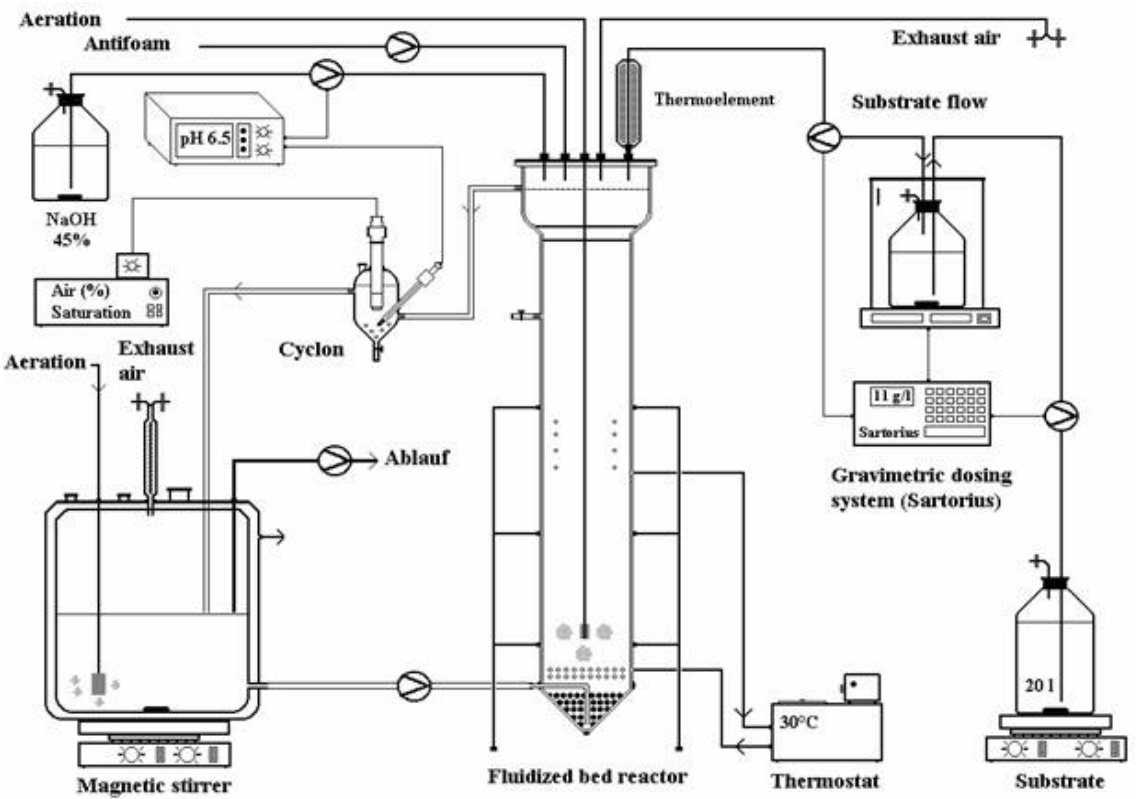

Figure 2. Flow scheme of a magnetic stirrer fermenter with intergraded fluidized bed reactor.

continuous feeding of medium started after the biomass reached a certain concentration of more than $3 \mathrm{~g} / \mathrm{l}$, in order to increase the load of biomass on the porous glass beads. The glass beads were overgrown from cells of $A$. Pullulans. $260 \mathrm{~g} / 1$ gluconic acid could be continuously obtained in fluidized bed reactor under steady state conditions at a retention time of $21 \mathrm{hrs}$ with a formation rate for the generic product gluconic acid of $12.4 \mathrm{~g} /(1 \mathrm{x} \mathrm{h})$. The adhesive behaviour of $A$. pullulans resulted in diffusion problems for the oxygen transfer and thus in oxygen limitation of the immobilized biomass.

\section{Continuous gluconic acid fermentation with biomass retention by means of microfiltration}

A good alternative approach for the acceleration of product concentration maximization is the partial retention of biomass by means of microfiltration (cross over filtration). Biomass retention enables the breaking of the link between growth (biomass formation) and residence time and between growth and production. It makes feasible the performance of the process at very high oxygen concentrations, which are toxic for cell growth, resulting in higher biomass specific productivities. It should also be examined, whether very high gluconic acid concentrations can be reached at shortened retention times, using very high oxygen concentrations. In order to receive comparable data, the experiments were accomplished under the same conditions as the preceding continuous fermentations without biomass retention. About $80 \%$ of filtrate (filtered fermentation solution) and $20 \%$ bleed (unfiltered fermentation solution) were adjusted and maintained constant during the entire duration of the experiment. Applying a glucose concentration of $450 \mathrm{~g} / \mathrm{l}, 375 \mathrm{~g} / \mathrm{l}$ gluconic acid was continuously produced at a residence time of about $22 \mathrm{hrs}, 100 \%$ conversion of glucose, $30^{\circ} \mathrm{C}$, $\mathrm{pH} 6.5$ and $290 \%$ air saturation by $23 \mathrm{~g} / \mathrm{l}$ of accumulated biomass. $370 \mathrm{~g} / \mathrm{l}$ of gluconic acid were also produced at 19 hrs and complete glucose conversion by a biomass of $25 \mathrm{~g} / 1$ (Table 1, Figure 4).

In previous studies, it has been extensively studied the influence of residence time on continuous production without biomass retention (Anastassiadis et al. 2003; Anastassiadis et al. 2005). In the present work, the maximization of gluconic acid concentration has been achieved by applying biomass retention in bioreactor by means of cross over filtration. According to present results, it seems very possible to still convert glucose completely at even very short residence times i.e. less than $7 \mathrm{hrs}$. The investigation of the performance of continuous gluconic acid production by biomass retention at very low residence times was not possible because of technical inadequacies.

\section{DISCUSSION}

Microbial production of metabolites of primary and intermediary metabolism usually takes place under stress conditions. The medium composition plays a crucial role for a successful metabolite production. Fermentation parameters such as $\mathrm{pH}$, oxygen, temperature and medium composition, influencing continuous and discontinuous gluconic acid production by isolated strains of $A$. pullulans, have been identified and optimized in previous chemostat studies (Anastassiadis et al. 1999; Anastassiadis et al. 2003; 
Anastassiadis et al. 2005). In a conventional chemostat culture without any biomass retention, where growth and production occur simultaneously, the wash out effect of biomass is the limiting factor in terms of achieving very high product concentrations at very low residence times (high dilution rates). The highest formation rate and specific productivity for the generic product gluconic acid have been achieved at lower residence times. They decrease continuously at increasing residence time and very high gluconic acid concentrations of more than $230 \mathrm{~g} / \mathrm{l}$ (Anastassiadis et al. 1999; Anastassiadis et al. 2003). The formation rate of the generic product $(\mathrm{Rj})$ is a compensation effect between biomass concentration and biomass specific production rate. In continuous process, growth and production run parallel, influencing each other. For example, different optimum dissolved oxygen concentrations have been determined for growth, gluconic acid production and for various specific fermentation factors such as conversion, formation rate for the generic product, specific gluconic acid productivity, selectivity and yield. Hence, the optimum fermentation parameters that had been found for example for the $\mathrm{pH}$, temperature and oxygen saturation are the compensation result between growth and production.

A gluconic acid concentration higher than $230 \mathrm{~g} / \mathrm{l}$ was continuously produced at residence times of $12 \mathrm{hrs}$ without any biomass retention (Anastassiadis et al. 2005). New alternative processes for the continuous production of very high gluconic acid concentrations using free growing cells or biomass retention of $A$. pullulans are described in the present work. Biomass retention by immobilization or cross over filtration enables the application of production optima in a continuous fermentation process even at very short times that would normally wash out the biomass from the fermenter. Thus, the maximum specific productivity of generic product can be maintained, uncoupling product formation from growth rate, although it differs from the optimum growth conditions. Biomass retention by means of cross over filtration makes it possible to break the existing link between growth and the residence time. A. pullulans was easily immobilized on porous sintered glass and suitable for a continuous gluconic acid production by immobilized cells. A good alternative for the acceleration of product concentration maximization offers the partial biomass retention by means of microfiltration (cross over filtration). Continuous fermentation can thus perform at optimum production parameters, which would not necessarily be optimal for the formation of biomass, thus breaking partially the interaction between growth and production. A very high formation rate and concentration of generic product can be obtained at simultaneously keeping very high specific productivities. Although continuous fermentation performing in a fluidized bed reactor with immobilized biomass on a support carrier may be more convenient from a process point of view, fermentation with non-supported microorganisms performing without or with biomass retention by cross over filtration has been found to be advantageously. In both cases, very high dissolved oxygen concentrations higher than $200 \%$ air saturation are applied successfully.

Early fungal fermentation processes for gluconic acid production employed species of Penicillium (Herrick and

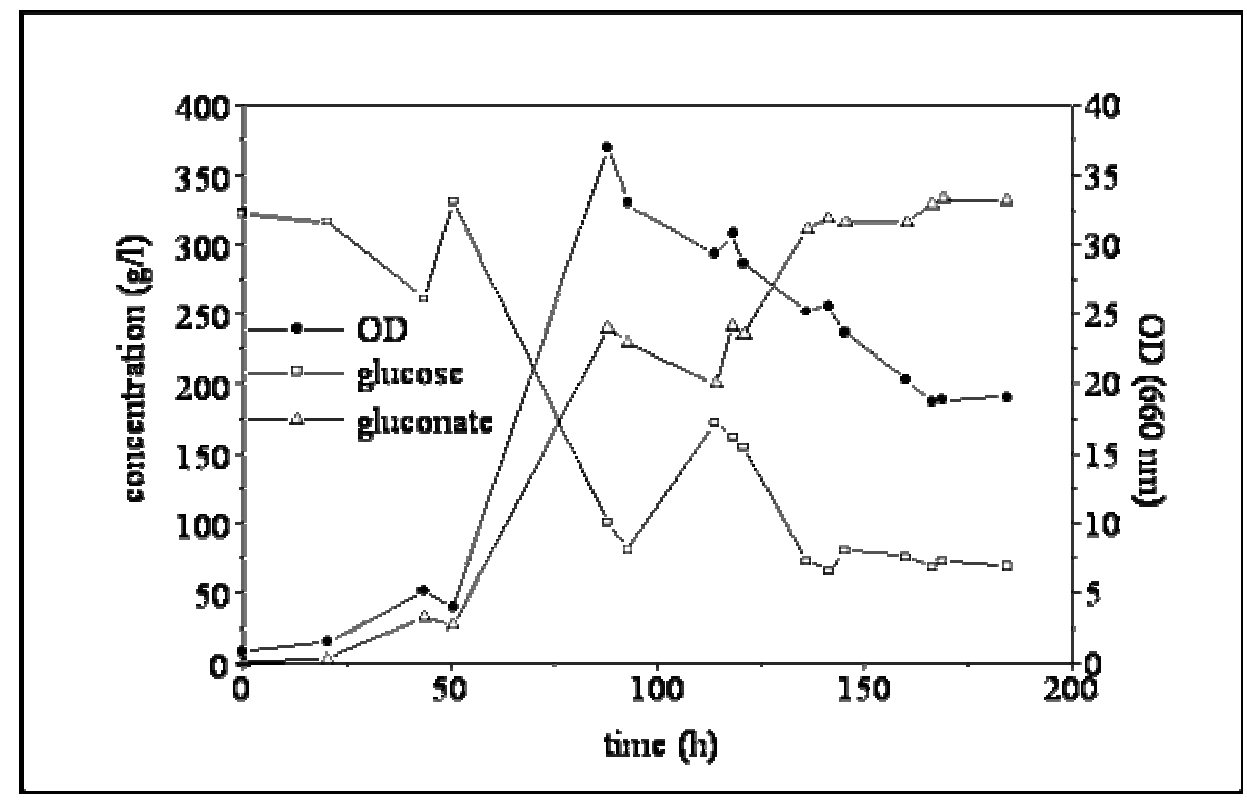

Figure 3. Continuous gluconic acid fermentation by free growing cells of $A$. pullulans at a residence time of $25 \mathrm{hrs}\left(3 \mathrm{~g} / \mathrm{l} \mathrm{NH} \mathrm{N}_{4} \mathrm{Cl}, 450 \mathrm{~g} / \mathrm{l}\right.$ glucose, $1 \mathrm{mM}$ iron, $5 \mathrm{mM}$ manganese, $\mathrm{pH} 6.5,30^{\circ} \mathrm{C}$ and $155 \%$ oxygen saturation). 


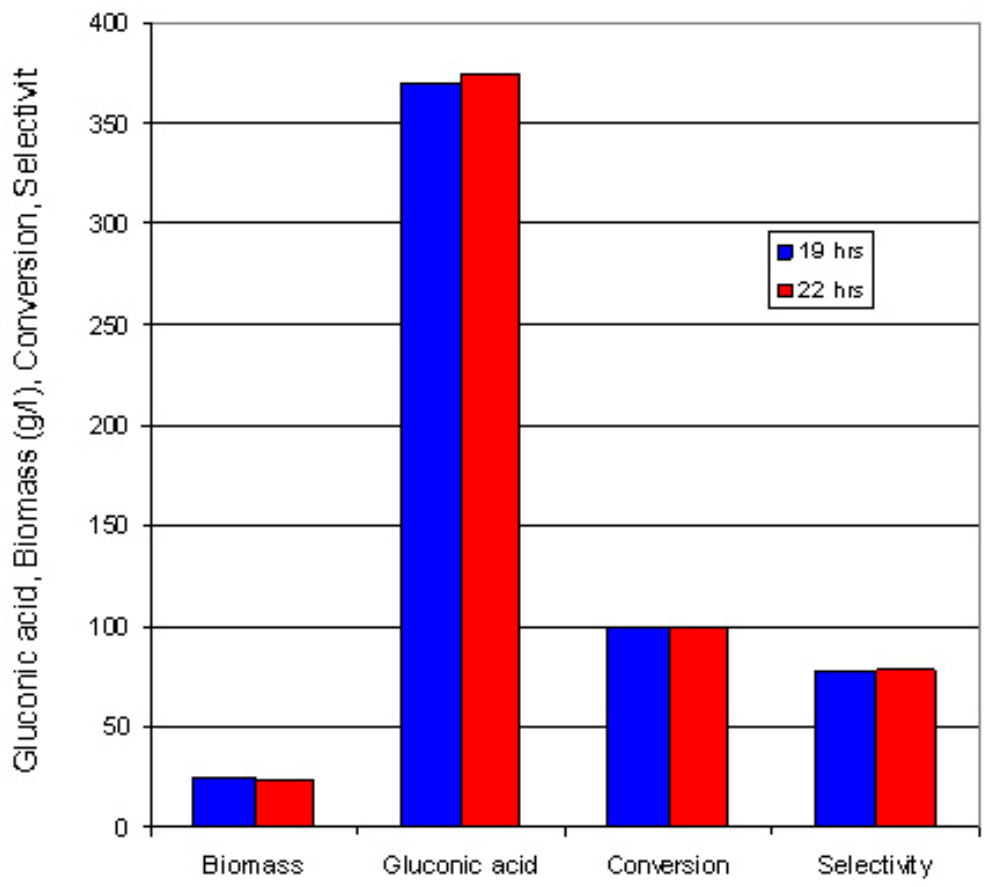

Figure 4. Continuous production of gluconic acid by cross over filtration.

May, 1928). Improved strains of Aspergillus niger (predominantly) with recycled mycelia or Gluconobacter suboxidans are used in discontinuous submerged fermentations in gluconic acid industry (Röhr et al. 1983). Gluconic acid formation carried out in shake flasks by the yeast-like mold Aureobasidium (former Dematium or Pullularia) pullulans, using various carbon sources, has been known since very long time (Pervozvansky, 1939; Takao and Sasaki, 1964; Sasaki and Takao, 1970). However, gluconic acid production by A. pullulans on an industrial scale, which is well characterized for the production of pullulan, stayed out of question and investigation.

To our knowledge, no comparable results reaching those high product concentrations (Anastassiadis et al. 1999; Anastassiadis et al. 2003; Anastassiadis et al. 2005; present work) can be found in the international literature, referring to the continuous gluconic acid production by free growing or immobilized cells of Aspergillus and Penicillium strains or other microorganisms, without any biomass retention. $260 \mathrm{~g} / 1$ of gluconic acid were continuously produced without any biomass retention under optimized conditions by $A$. pullulans at $15.3 \mathrm{hrs}$ RT and $305-315 \mathrm{~g} / \mathrm{l}$ at about 21 hrs. $370 \mathrm{~g} / \mathrm{l}$ of gluconic acid were also continuously produced at complete glucose conversion at $19 \mathrm{hrs}$ residence time and up to $504 \mathrm{~g} / 1$ were achieved in fed batch experiments (Anastassiadis et al. 1999; Anastassiadis et al. 2003; present work). Sankpal et al. (1999) reported about continuous gluconic acid production by immobilized mycelia of $A$. niger achieving 120-140 g/l gluconic acid. The repeated reuse of cell mycelia has been reported as an option of semi-continuous production of gluconic acid by A. niger (Hatcher, 1972). Alternatively, high gluconate concentrations and very high productivities were achieved by the fed-batch-wise addition of large amounts of glucose into fermenter using $A$. niger. However, the productivity became unattainable after a few repetitions, whereas $220 \mathrm{~g} / 1$ gluconate were repeatedly produced 14 times, using immobilized mycelia on a non-woven fabric within a period of about 1,000 hrs (Sakurai et al. 1989). A product inhibition has been observed in $A$. pullulans process at gluconic acid concentrations above $250 \mathrm{~g} / 1$ in good agreement to reports of Gastrock et al. (1938), Lee et al. (1987) and Sakurai et al. (1989) for A. niger (300 g/l).

Knowingly, $A$. niger is difficult to handle because of causing clogging problems during the fermentation and unsuitable for a continuous operation using free growing cells. Gluconobacter has been reported to produce a relative large quantity of keto-acids during the production of gluconic acid (Elfari et al. 2005), thus complicating down streaming processing and the isolation of gluconic acid. Velizarov and Beschkov (1998) reported about a rapid decrease of conversion in Gluconobacter oxydans at glucose concentrations higher than $0.56 \mathrm{M}$. Increasing additions of gluconic acid to the medium resulted in extended lag phases of growth and the maximum possible 
gluconic acid concentration has been approximated at 0.7 M (Velizarov and Beschkov, 1998). For comparison, the continuous operations using $A$. pullulans show many advantages compared with the traditional discontinuous fungi and bacterial processes. Under optimized fermentation conditions, it proved to be a superior gluconic acid producer, which can be used in continuous culture for a very long period without any stability problems. The yeast like fungus Aureobasidium pullulans integrates the advantages of fungal and bacterial systems at once. It is enabled to utilize astonishingly very high glucose concentrations in continuous single or two stage mode reaching very high gluconic acid concentrations of 200-433 at residence times between 10 and $38 \mathrm{hrs}$ and a maximum biomass specific productivity of about $10 \mathrm{~g} /(\mathrm{g} \times \mathrm{x})$ (Anastassiadis et al. 1999; Anastassiadis et al. 2003; Anastassiadis et al. 2005). In comparison, Roukas and Harvey (1988) reached $16 \mathrm{~g} / \mathrm{l}$ gluconic acid by free growing cells of $A$. niger at $83 \mathrm{hrs}$ residence time. Babel and Müller (1987) obtained $208 \mathrm{~g} / \mathrm{l}$ of gluconic acid at 40 residence time using Acetobacter methanolicus, whereas up to $295 \mathrm{~g} / 1$ have been continuously produced by permeabilized cells of Zymomonas mobilis in about $75 \mathrm{hrs}$ (Rehr et al. 1991). In a continuous process for the simultaneous production of sorbitol and gluconic acid, the use of cell-free glucosefructose oxidoreductase from $Z$. mobilis requires the efficient stabilization of the enzyme (Gollhofer et al. 1995).

The use of genetically engineered microorganisms and the immobilization of isolated glucose oxidizing enzymes or whole cells in specialized reactors appear in literature reports as the possible future developments regarding the advanced continuous production of gluconic acid (Hartmeier and Döppner, 1983; Milson, 1987; Szajani et al. 1987). Park et al. (2000) cloned and expressed for example glucose oxidase from A. niger in Saccharomyces cerevisiae using a yeast shuttle vector. Specialized reactors (Basseguy et al. 2004; Godjevargova et al. 2004) and genetic programming, as well as multicriteria optimization strategies (Cheema et al. 2002; Halsall-Whitney et al. 2003) have been applied for the production of gluconic acid as well. The fact that the present superior results were reached using a wild strain as it has been isolated from the nature and without the involvement of any classical or genetic engineering mutagenesis approaches clearly emphasize the nature's great latent and still unknown potential for further future biotechnological achievements. The development of the present superior fermentation processes has accomplished the highest expectations of an expertise researcher in the field of industrial microbiology and biotechnology, extending the frontiers of known microbial capabilities and emphasizing the importance of the deep understanding of classical and industrial microbiology in the field of biotechnology science. The novel continuous and discontinuous fermentation processes of Aureobasidium pullulans, applying or not biomass retention, offer new opportunities and are very promising for future applications for the commercial production of gluconic acid. The new processes can last in today's high competitiveness in industry, claiming numerous advantages over the traditional fungi or bacteria processes of the last 100 years. A continuous industrial production of the responsible glucose oxidizing enzyme from $A$. pullulans appears feasible as well.

The process operation is very stable, under the condition that filter modules are cleaned (periodical reverse flow of filtrate). A precondition for an unproblematic long time operation is also keeping the system safe from contaminations, because some contaminants can overgrow the production strain. No strain instabilities have been observed so far during the extensive process optimization and development program, showing the genetic stability of the new yeast-like mold system.

\section{CONCLUDING REMARKS}

Such data of reaching very high gluconic acid concentrations, which are stably obtained for a very long time under continuous cultivation using free growing chemostat cells without any biomass retention, have not been published in the international literature before. The very high product molar and mass selectivities, reaching more than $100 \%(\mathrm{~g} / \mathrm{g})$, show that the new process would be a favourable alternative for the industrial production of gluconic acid compared with the discontinuous fungi processes of the last 100 years. Even $504 \mathrm{~g} / \mathrm{l}$ of gluconic acid were achieved in fed-batch fermentations using $A$. pullulans isolate 70 (Anastassiadis et al. 1999; Anastassiadis et al. 2003; Anastassiadis et al. 2005). Interesting future research works would include the investigation of continuous gluconic acid production, using biomass retention by cross over filtration, at different residence times and at varying the proportion ratio between filtrate and bleed stream. Mathematical models would enable the prediction of experimental results at various stream ratios and facilitate future research designs and experimental plans.

\section{ACKNOWLEDGMENTS}

We thank Prof. Dr. Christian Wandrey (Institute of Biotechnology 2 of Research Center Jülich, RCJ, Germany; formerly known as Nuclear Research Center Jülich, KFA) for his helpful advices and support.

\section{DECLARATION}

The experiments of the present manuscript comply with the currant laws of the country Germany (Institute of Biotechnology 2 of Research Center Jülich 2, RCJ) where the experiments were performed.

\section{REFERENCES}

ANASTASSIADIS, Savas. Determination of organic acids, especially citricacid and isocitric acid, in fermentation solutions and fruit juices. In: HPLCApplications, 
MACHEREY-NAGEL GmbH \& Co. KG (D?ren, Germany), 1993, Application no. 8, p. 4.

ANASTASSIADIS, Savas, AIVASIDIS, Alexander and WANDREY, Christian. Process for the production of gluconic acid with a strain of Aureobasidium pullulans (De Bary) Arnaud. US Patent No. 5,962,286, October 5, 1999.

ANASTASSIADIS, Savas; AIVASIDIS, Alexander and WANDREY, Christian. Citric acid production by Candida strains under intracellular nitrogen limitation. Applied Microbiology Biotechnology, October 2002, vol. 60, no. 12, p. 81-87.

ANASTASSIADIS, Savas; AIVASIDIS, Alexander and WANDREY, Christian. Continuous gluconic acid production by isolated yeast-like mould strains of Aureobasidium pullulans. Applied Microbiology and Biotechnology, April 2003, vol. 61, no. 2, p. 110-117.

ANASTASSIADIS, Savas; AIVASIDIS, Alexander; WANDREY, Christian and REHM, Hans-Jürgen. Process optimization of continuous gluconic acid fermentation by isolated yeast-like strains of Aureobasidium pullulans. Biotechnology and Bioengineering, August 2005, vol. 91, no. 4, p. 494-501.

BABEL, W. and MÜLLER, R.H. A procedure for gluconic acid synthesis with bacteria made continuous by means of an auxiliary substrate. Acta Biotechnologica, 1987, vol. 7, no. 3 , p. 285-288.

BANG, W.; LU, X.; DUQUENNE, A.M.; NIKOV, I. and BASCOUL, A. Glucose oxidation in a three-phase stirred airlift reactor: experiments and model. Catalysis Today, January 1999, vol. 48, no. 1-4, p. 125-130.

BAO, Jie; FURUMOTO, Keiji; FUKUNAGA, Kimitoshi and NAKAO, Katsumi. A kinetic study on air oxidation of glucose catalyzed by immobilized glucose oxidase for production of calcium gluconate. Biochemical Engineering Journal, September 2001, vol. 8, no. 2, p. 91-102.

BASSEGUY, R.; DELECOULS-SERVAT, K. and BERGEL, A. Glucose oxidase catalysed oxidation of glucose in a dialysis membrane electrochemical reactor (DMER). Bioprocess and Biosystems Engineering, April 2004, vol. 26, no. 3, p. 165-168.

BLANDINO, A.; MACIAS, M. and CANTERO, D. Immobilization of glucose oxidase within calcium alginate gel capsules. Process Biochemistry, February 2001, vol. 36, no. 7, p. 601-606.

CHEEMA, Jitender Jit Singh; SANKPAL, Narendra V.; TAMBE, Sanjeev S. and KULKARNI, Bhaskar D. Genetic programming assisted stochastic optimization strategies for optimization of glucose to gluconic acid fermentation.
Biotechnology Progress, December 2002, vol. 18, no. 6, p. 1356-1365.

ELFARI, Mustafa; HA, Seung-Wook; BREMUS, Christoph; MERFORT, Marcel; KHODAVERDI, Viola; HERRMANN, Ute; SAHM, Hermann; GORISCH, Helmut. A Gluconobacter oxydans mutant converting glucose almost quantitatively to 5-keto-D-gluconic acid. Applied Microbiology and Biotechnology, March 2005, vol. 66, no. 6, p. 668-674.

FENICE, Massimiliano; SELBMAN, Laura; FEDERICI, Federico and VASSILEV, Nikolay. Application of encapsulated Penicillium variabile P16 in solubilization of rock phosphate. Bioresource Technology, June 2000, vol. 73 , no. 2 , p. $157-162$.

FERRAZ, Helen C.; BORGES, Cristiano P. and ALVES, Tito Lívio M. Sorbitol and gluconic acid production using permeabilized zymomonas mobilis cells confined by hollow-fiber membranes. Applied Biochemistry and Biotechnology, 2000, vol. 89, no. 1, p. 43-54.

GASTROCK, E.A.; FORGES, N.; WELLS, P.A. and MOYER, A.J. Gluconic acid production on pilot-plant scale, effect of variables on production by submerged mold growths. Industrial \& Engineering Chemistry, 1938, vol. 30, p. 782-789.

GODJEVARGOVA, Tzonka; DAYAL, Rajeshwar and TURMANOVA, Sevdalina. Gluconic acid production in bioreactor with immobilized glucose oxidase plus catalase on polymer membrane adjacent to anion-exchange membrane. Macromolecular Bioscience, October 2004, vol. 4, no. 10 , p. $950-956$.

GOLLHOFER, Dorothee; NIDETZKY, Bernd; FUERLINGER, Monika and KULBE, Klaus D. Efficient protection of glucose-fructose oxidoreductase from Zymomonas mobilis against irreversible inactivation during its catalytic action. Enzyme and Microbial Technology, March 1995, vol. 17, no. 3, p. 235-240.

GROMADA, A. and FIEDUREK, J. Selective isolation of Aspergillus niger mutants with enhanced glucose oxidase production. Journal of Applied Microbiology, May 1997, vol. 82 , no. 5, p. 648-652.

HALSALL-WHITNEY, H.; TAYLOR, D. and THIBAULT, J. Multicriteria optimization of gluconic acid production using net flow. Bioprocess and Biosystems Engineering, March 2003, vol. 25, no. 5, p. 299-307.

HARTMEIER, W. and DÖPPNER, Theresia. Preparation and properties of mycelium bound glucose oxidase coimmobilized with excess catalase. Biotechnology Letters, November 1983, vol. 5, no. 11, p. 743-748. 
HATCHER, H.-J. Gluconic acid production. United States Patent No. 3,669,840, 1972.

HERRICK, Horace T. and MAY, Orville E. The production of gluconic acid by the Penicillium luteum-purpurogenum Group II. Some optimal conditions for acid formation. The Journal of Biological Chemistry, April 1928, vol. 77, no. 1, p. 185-195.

HUSTEDE, H; HABERSTROH, H.J. and SCHINZIG, E. Gluconic acid. In: ULLMANN'S Encyclopedia of Industrial Chemistry, Weinheim 1989, vol. A 12, p. 449-456.

KARA, A. and BOZDEMIR, T.O. Optimization of the growth parameters of Aspergillus foetidus. Acta Biotechnologica, 1998, vol. 18, no. 4, p. 327-338.

KLEIN, Jaroslav; ROSENBERG, Michael; MARKO, Jozef; DOLGO, Ondrej; KROSLAK, Marek and KRISTOFIKOVA, L'udmila. Biotransformation of glucose to gluconic acid by Aspergillus niger-study of mass transfer in an airlift bioreactor. Biochemical Engineering Journal, April 2002, vol. 10, no. 3, p. 197-205.

LEE, H.W.; SATO, S.; MUKATAKA, S. and TAKAHASHI, J. Studies on production of gluconic acid by Aspergillus niger under high dissolved concentration. Journal of Fermentation Technology, 1987, vol. 65, p. 501506.

MILSON, P.E. Organic acid fermentation, especially citric acid. Food Biotechnology, 1987, vol. 1, p. 273-307.

MUKHOPADHYAY, R.; CHATTERJEE, S.; CHATTERJEE, B.P.; BANERJEE, P.C. and GUHA, A.K. Production of gluconic acid from whey by free and immobilized Aspergillus niger. International Dairy Journal, March 2005, vol. 15, no. 3, p. 299-303.

NAKAO, Katsumi; KIEFNER, Andreas; FURUMOTO, Keiji and HARADA, Tsuyoshi. Production of gluconic acid with immobilized glucose oxidase in airlift reactors. Chemical Engineering Science, November 1997, vol. 52, no. 21-22, p. 4127-4133.

PARK, Eun-Ha; SHIN, Young-Mi; LIM, Young-Yi; KWON, Tae-Ho; KIM, Dae-Hyuk and YANG, Moon-Sik. Expression of glucose oxidase by using recombinant yeast. Journal of Biotechnology, July 2000, vol. 81, no. 1, p. 3544.

PERVOZVANSKY, V.V. Formation of gluconic acid during the oxidation of glucose by bacteria. Microbiology (U.S.S.R.), 1939, vol. 8, p. 149-159.

PRONK, J.T.; LEVERING, P.R.; OLIJVE, W. and VAN DIJKEN, J.P. Role of NADP-dependent and quinoprotein glucose dehydrogenases in gluconic acid production by Gluconobacter oxydans. Enzyme and Microbial Technology, March 1989, vol. 11, no. 3, p. 160-164.
REHR, Bert; WILHELM, Cornelia and SAHM, Hermann. Production of sorbitol and gluconic acid by permeabilized cells of Zymomonas mobilis. Applied Microbiology and Biotechnology, May 1991, vol. 35, no. 2, p. 144-148.

RODRIGUEZ, Hilda; GONZALEZ, Tania; GOIRE, Isabel and BASHAN, Yoav. Gluconic acid production and phosphate solubilization by the plant growth-promoting bacterium Azospirillum spp. Naturwissenschaften, November 2004, vol. 91, no. 11, p. 552-555.

RÖHR, M.; KUBICEK, C.P. and KOMINEK, J. Gluconic acid. In: REHM, H.J. and REED, G. eds. Biotechnology, Verlag Chemie, Weinheim-Deerfield, vol. 3, 1983, p. 456465.

ROUKAS, T. and HARVEY, L. The effect of $\mathrm{pH}$ on production of citric and gluconic acid from beet molasses using continuous culture. Biotechnology Letters, April 1988, vol. 10, no. 4, p. 289-294.

SAKURAI, Hiroshi; LEE, Hang Woo; SATO, Seigo; MUKATAKA, Sukekuni and TAKAHASHI, Joji. Gluconic acid production at high concentrations by Aspergillus niger immobilized on a nonwoven fabric. Journal of Fermentation and Bioengineering, 1989, vol. 67, no. 6, p. 404-408.

SANKPAL, N.V.; JOSHI, A.P.; SUTAR, I.I. and KULKARNI, B.D. Continuous production of gluconic acid by Aspergillus niger immobilized on a cellulosic support: study of low $\mathrm{pH}$ fermentative behaviour of Aspergillus niger. Process Biochemistry, November 1999, vol. 35, no. 3-4, p. 317-325.

SANKPAL, N.V. and KULKARNI, B.D. Optimization of fermentation conditions for gluconic acid production using Aspergillus niger immobilized on cellulose microfibrils. Process Biochemistry, July 2002, vol. 37, no. 12, p. 1343-1350.

SASAKI, Y. and TAKAO, S. Gluconic acid fermentation by Pullularia pullulans II. Acid production from various carbon sources. Journal of Fermentation Technology, 1970, vol. 48, p. 368-373.

SINGH, N.B. Effect of gluconates on the hydration of cement. Cement and Concrete Research, July 1976, vol. 6, no. 4, p. 455-460.

SZAJANI, B.; MOLNAR, A.; KLAMAR, B. and KALMAN, M. Preparation, characterization, and potential application of an immobilized glucose oxidase. Applied Biochemistry and Biotechnology, 1987, vol. 14, p. 37-47.

TAKAO, S. and SASAKI, Y. Gluconic acid fermentation by Pullularia pullulans Part I. Screening of gluconic acidproducing strains and some conditions for its production. Agricultural and Biological Chemistry, 1964, vol. 28, no. 11 , p. $752-756$ 
VASSILEV, Nikolay; VASSILEVA, Maria; FENICE, Massimiliano and FEDERICI, Federico. Immobilized cell technology applied in solubilization of insoluble inorganic (rock) phosphates and $\mathrm{P}$ plant acquisition. Bioresource Technology, September 2001, vol. 79, no. 3, p. 263-271.

VELIZAROV, S. and BESCHKOV, V. Biotransformation of glucose to free gluconic acid by Gluconobacter oxydans: substrate and product inhibition situations. Process Biochemistry, June 1998, vol. 33, no. 5, p. 527-534.

ZNAD, H.; MARKOS, J. and BALES, V. Production of gluconic acid from glucose by Aspergillus niger: growth and non-growth conditions. Process Biochemistry, July 2004, vol. 39, no. 11, p. 1341-1345. 